\title{
Pawn To King Four: Sermon Introductions And Communicational Design
}

\section{THOMAS G. LONG}

One of the many recent advances in contemporary homiletical theory has involved the acknowledgement of the inter-relatedness of the various aspects of sermon development. It is no longer thought sufficient to divide the process of sermon construction into separate "stages," such as "exegesis," "theological analysis," "outlining," "illustrating the sermon," "delivery," and so on. We discuss these aspects, of course, but only in the full awareness that, when all is said and done, they are not, in fact, discrete, but rather interpenetrating, realities and that each has much to do with all of the others.

How the preacher encounters and understands the biblical text, at one end of the process, for example, already bears (or should bear) upon delivery, at the other end. For instance, a biblical text which achieves its impact through irony or poetic imagery calls for something more than a flat-footed, schoolmaster's delivery. A text which embraces a confident and ringing affirmation of the gospel calls the preacher, not to deliver a "book report" on the text, but rather to an embodiment of the text's assurance (or at least an involved response to the text's boldness). In one sense there is nothing new about all of this. Good preachers have known for a long time that tugging at any single thread in the sermonic fabric causes the whole cloth to gather. What is new is that the concept of the inter-relatedness of the sermon development process has moved from intuitive practice to the level of theory. The fact that biblical scholars themselves are now doing such things as looking for "literary patterns" and "rhetorical cues" in texts only brings confirmation, theoretical precision, and methodological refinement to what preachers have long been doing by the seat of their pants and the hems of their skirts.

\section{Sermon Unity: A New Perspective}

This grasp of the inter-relatedness of the various portions of the sermon development process has also transferred to the sermon itself. Sermons are now viewed as dynamic organisms, in which each part affects - and is affected by - all the others. This makes it inadequate to think, for example, of "finding an illustration to plug into a sermon," as if sermons were like chandeliers into which pieces, like bulbs, could be inserted and replaced at will, as if a change in one part of a sermon did not affect the whole.

This view of sermonic unity is not really new, either. Sermons have never really been seen, except in some exceedingly scholastic homiletics texts, as consisting of a set of ideas or units strung together, sharing a common theme, but otherwise disconnected. There has always been at least some awareness that the various facets of the sermon work together in some common act of communication. There is fairly good evidence that even the synogogue 
sermons of the first century, which almost surely were the models for early Christian preaching, were constructed according to a rather sophisticated theme which involved the interlacing of the Torah and Prophetic readings toward the goal of demonstrating what the one had to say about the other. This afforded no little opportunity for the best of the rabinnical orators to show off, flaunting their creative skills and dazzling the hearers with the many layers at which the law and the prophets could be seen to speak to each other.

What is new in recent homiletics is the degree of theoretical precision which is beginning to be brought to bear upon the task of understanding how one portion of the sermon serves, and is served by, the others. Sermons are now seen to be "systems of communication," a ghastly phrase to be sure, but a helpful analytical abstraction nonetheless. Nowadays, when a teacher of preaching tells a student that a certain kind of "illustration" is needed at such and such a point in the sermon, this advice does not have to be made on the basis of some mechanical pattern of sermon design (e.g., "each 'point' should have an illustration") or on some pseudo-psychological understanding of communication (e.g., "the congregation needs a 'break' between points."). It can be made out of a larger vision of the communicational work of the whole sermon and how it is that each aspect of the sermon picks up a piece of that total task.

\section{Introductions: A Test Case}

One place we can see the impact of this revisioning of the sermon is in the way contemporary homileticians discuss the traditional topic of sermon structure, or "outlines." Some of them find the word "outline" to be hopelessly mired in pedantic and deductive conceptions and refuse to use it at all, preferring a more fluid notion, like "plot" or "shape." Even when the term "outline" is retained, though, it is clear that the focus of the discussion has changed. The older preaching texts tended to discuss outlining as the way in which the content of the sermon was arranged. The newer texts make the shift from content to communication. A sermon outline, plot, shape, or whatever term is used, is not merely a description of the way in which the sermon's content is arrayed. It is a description of the process of communication between preacher and hearers. Sermons are designed in specific patterns not merely because the content assumes a certain form (e.g., "There are four claims this text makes about faith ... "), but because of the ways in which people listen. The main question is not, "How can this material be divided?," but rather, "How can people best hear this material?"

An examination of the role of sermon beginnings, or "introductions," can serve as a revealing test case of this newer integrative approach to preaching theory. An "introduction" is not simply the way the content of the sermon begins. It is also the way in which a certain phase of the communication between preacher and hearer begins. We need, then, to ask about the role beginnings play in the whole process of sermon communication.

\section{Sermon Introductions In Recent Homiletics}

When George Buttrick said that preachers should prepare a sermon introduction which is "brief, interesting, and raises the issue," he said everything - and nothing. Properly 
exegeted, Buttrick's rule perhaps says all that can or should be said on the subject. The problem, however, is that considerable exegesis is needed to appreciate the value of the rule, and Buttrick's dictum has often been employed in a clumsy manner. If Buttrick is merely giving a three-fold check list, then the first item ("brevity") is mis-identified, the second ("interesting") is obvious, and the third ("raises the issue") is biased toward an overly cognitive approach to preaching. Good sermon introductions usually are brief, but this is not because brevity is a self-contained virtue. Introductions are doing something in and for the whole sermon which can, in most cases, be done best when they are brief, but it is this communicational action which must be named, not the by-product of brevity. If being "uninteresting" is the alternative, then introductions surely ought to be "interesting," but so should "middles" and "conclusions." What needs to be specified is the particular kind of interest which introductions have as their task to arouse. To say that introductions should "raise the issue" of the sermon comes closer to the kind of specificity needed, as long as "the issue" is not misconstrued to read "state the thesis" or some similar language of ideational abstraction.

In his recent book Fundamentals of Preaching, John Killinger borrows Buttrick's formula (translated as "brief, arresting, and conductive") and adds a virtue to the list: memorable. $^{2}$ This is an interesting addition, mainly because Killinger may be on to more than he is aware. What Killinger really wants to say, I think, is not that sermon introductions ought to be memorable, but that sermons themselves ought to be memorable and that introductions can contribute to that characteristic. In other words, introductions are evaluated on the basis of their contributions to the sermon as a whole, rather than in isolation from the other aspects of the sermon.

Grady Davis, whose Design for Preaching served as a standard homiletics textbook for many years, also followed Buttrick in regard to introduct:ons, but advanced the discussion by doing so in a far more sophisticated and complex manner than most. Davis conceived of a sermon on the model of a sentence. Each sermon consists of a subject (what the sermon is about) and a predicate (the one main thing which the sermon says about the subject). The predicate is further divided into a series of assertions, two to six claims which develop the subject and which form the logical flow, or continuity, of the sermon. Davis elaborates this basic "design" in four ways. First, he identifies three possible functions, or purposes, of a sermon: proclamation, teaching, and therapy. Second, he names five different organic forms, or organizing principles, for sermons: a subject discussed, a thesis supported, a message illumined, a question propounded, and a story told. Third, he specifies four types of sermon continuity, or flow: deductive, inductive, logical, and chronological. Finally, he suggests three tenses, or modes, of preaching: imperative, conditional, and indicative.

Taken seriously, of course, Davis' scheme is an immensely complex model of preaching, and the usefulness of some of his categories justly deserves challenge. It would take more space than we have here to elaborate upon and criticize Davis' schema, and that is not our main concern. The crucial point we wish to make is that Davis was among the first to discern the organic communicational unity of sermons and to attempt to mold homiletical practice around that theoretical vision. When he gets around to introductions, he remains faithful to his theory, maintaining that "the introduction should be thought of as the first two minutes 
of a twenty- to twenty-five minute experience by the people of the sermon's thought." ${ }_{3}$ In other words, the introduction is the first in a series of communicational moves, each linked to the others, one phase in a comprehensive experience of listening. Davis knows that the introduction is a piece of the sermon fabric not to be considered apart from the whole garment. It sets the stage for the complete sermon and, as such, establishes limits on the style, tone, form, and purpose of the rest of the sermonic communication. ${ }^{4}$

The next real advance in understanding the role and communicative value of sermon introductions comes from human communication science, as brokered into the homiletical field by J. Randall Nichols in his Building the Word. Nichols maintains that the purpose of an introduction is ...

. . to establish between preacher and hearers a "contract for communication,"

a shared agreement that in the message to follow we will be talking about certain things in certain ways, trying to get certain points of understanding or action, and each contributing this or that to the unfolding process."

Now, at first glance, this appears to be a nice restatement of Davis. In the introduction we talk about certain things (the subject) in certain ways (the organic form), to get certain points of understanding (the assertions), and so on. But what sets Nichols' view apart is the crucial distinction he makes between "communication," per se, and "meta-communication," or communication about communication. Nichols is aware, of course, that introductions have communicational value in that they have "some informational relationship to the 'body' of the message," but that is not what concerns him. His interest, and his contribution, is the realization that introductions serve a meta-communicational purpose, that is, they serve as the basis of an agreement between the preacher and the hearers "about how we will handle and what we will make of the message content which is to come." As such, the introduction to the sermon is analogous to the "contract" made between a pastoral counselor and the counselee "to work toward certain goals and in certain ways between care giver and receiver."

What we have in Nichols, then, is a genuine innovation in homiletical theory: a thoroughgoing analysis of sermon introductions done from a communicational vantage point. Nichols has his eye on the listening process, on what happens between the preacher and the hearer. This view of the introduction allows Nichols to dismiss two of Buttrick's time-worn criteria as misplaced categories. "The communication question to ask," claims Nichols, "is 'When has the contract been set?' rather than 'How long should the introduction be?' " So much for brevity. Nichols has gone beneath the superficial quality to discern the communicational dynamic. As for the demand that the introduction be "interesting," Nichols states the following:

Time after time we have heard that the purpose of an introduction is to 'get people's attention.' Now really, when was the last time anyone saw a preacher step into the pulpit at sermon time and not have everyone's attention ... We do not need to 'get it,' but we surely do need to use it by establishing a contract for communication. ${ }^{6}$

Nichols acknowledges - and addresses - two potential objections to his view of introductions. First, there is the objection that clearly setting out the contract of the sermon will spoil those sermons which are built around a discovery process of communication. Revealing 
everything in the beginning would, in effect, ruin the surprise. This would not only be a disappointment for the preacher, but, more important, for the hearers as well, who relish such experiences. Nichols answers that this objection misses the communication/meta-communication distinction. The introduction can contract with the hearers to join with the preacher in a thinking-through process toward an as-yet-undisclosed point. Thus, the contract is clear while, at the same time, the surprise remains intact.

The second objection addressed by Nichols is an aesthetic one, namely that the business of setting a contract inevitably involves the kind of technical, cards-on-the-table language which could mar a poetic and lyrical sermon. Nichols concedes that this is on occasion true (though not as often as would-be homiletical poets think). He suggests that these rare occasions can be handled by announcements about the nature of the sermon in the bulletin, elsewhere in the service of worship, or as a preface to the sermon itself.

Nichols' main point seems to be that listening to sermons is demanding work and that hearers have the need and right to know what they are in for. The introduction recognizes and respects the work of the listener by stating the nature of the task and inviting the hearer to accept his or her end of the cooperative task of co-creating the communication event of preaching.

\section{A Critique}

Nichols' work is clearly the most advanced statement to date on the nature of sermon introductions. A sermon is not primarily a literary product; it is essentially an act of proclamation. Whatever literary and aesthetic merits a sermon may possess, they must be subordinated to the larger concern that the sermon communicate something to those who hear. By introducing communicational concepts into the discussion, Nichols has refashioned the agenda in a helpful way and cleared' the homiletical landscape of much clutter. Any further advance in understanding what a sermon introduction should be must begin by considering Nichols' position.

Without taking away from Nichols' contributions, which are significant, I want to raise two objections to his view on the way toward making what I hope will be a constructive proposal regarding the role sermon introductions play in sermons:

1. I will begin by conceding the main point: introductions do involve what Nichols calls "meta-communication" in that they signal to the hearer certain cues about the communication event which is to follow. Meta-communication, however, is not a characteristic of introductions alone, but rather occurs throughout the sermon. What conventional homiletics has called "transitions" are often particularly high in meta-communicational content. It is not strictly accurate, then, to suggest that the introduction is the place in the sermon where meta-communication occurs. What does happen there might best be termed "introductory meta-communication," which, in a way, sends us back around to our original question: What can be said about the special role of introductions?

2. Nichols recognizes that meta-communication can be "sometimes overt and sometimes implicit," but he clearly pushes toward the more explicit variety, complaining that "we 
probably err in introductions more on the side of subtlety than overdirection." One is left with the impression that there are two almost discrete classes of statements: communicational ones, which involve certain kinds of information, and meta-communicational ones, which are directions or proposals for how the first class of statements shall be handled. Nichols knows that introductions contain examples of the first class of statements, but these do not attract his interest much. It is the second class of statements which is really important in an introduction, since a cluster of such statements can serve as the contractual agreement for the communicational tasks of preacher and listener throughout the sermon. This not only deprives us of Nichols' wisdom about what introductions ought to be in terms of communication content, but it also obscures the fact that meta-communication is most often a simultaneous, and not a separate, activity in human communication. I do not need (or want) formal instruction in meta-communication to know that "Dearly Beloved, we are gathered here in the presence of God ..." is a piece of information which has to be handled differently from "Did ya' hear the one about the sailor and the parrot?" These statements, like most human utterances, contain their own meta-communicational cues.

The point here is not that meta-communication ought to go on; it does go on whether we want it to or not. Part of Nichois' argument and contribution is that preachers need to become aware of this process and, to some degree, control it. Agreed, but I would insist that, most of the time, effective meta-communication occurs not by stepping aside and uttering several examples from a special class of meta-communicative statements, but rather by recognizing and regulating the meta-communicational overtones inherent in ordinary communication.

\section{Sermon Introductions: A Proposal}

So, what can we say about sermon introductions which would employ the insight of communication theory while at the same time avoiding some of the problems of Nichols' approach? I want to make six observations about sermon introductions. More observations need to be made before this can come close to a complete theory of introductions, but perhaps the bare outlines of a theory can already be seen here:

1. If there is anything which should have been made clear by the above discussion it is that it is not appropriate to speak about sermon introductions in isolation from their placement in the overall network of sermonic communication. An introduction gets the conversation going between the preacher and the hearers, and it already anticipates where that conversation will move. The way in which a sermon begins governs, to some degree, how that sermon can develop and how it can end.

2. This means that all homiletical descriptions of "good" introductions which are based upon the identification of self-contained virtues (such as "brevity" or "memorability") can be dismissed. Introductions cannot be "good" in and of themselves, but only in reference to the effectiveness of their role in the whole sermon.

3. This also means that introductions function as the first "step" in the sermon journey toward a "destination." The term "destination" can be defined in communicational terms as a certain form of psychological awareness which is present in the hearer at the end of the 
sermon and which the sermon played an important role in creating. It can be further described with reference to the familiar triad, knowing-being-doing. The preacher hopes that at the end of a sermon the hearers will know some things they did not previously know, feel some things they did not previously feel, be ready to act in certain new ways, or some combination of these. There is, in other words, a certain psychic distance to be traveled, and the sermon is a kind of guided journey from "here" to "there." The introduction must, of course, begin "here," but it must also anticipate "there."

4. An introduction begins "here" when it raises, implicitly or explicitly, some issue, problem, question, need, or situation which is recognized and construed to be important by the hearer. This is not to say, a la Fosdick, that introductions are condemned to the presentation of "life situations." Indeed, the introduction may be a description of Assyrian cultic practices, but it must include signals to the hearer about why listening to this material is pertinent and worthwhile and at least some hint about how this material will be valuable to the sermon event as a whole. Listening to a sermon is active not passive, and part of the activity of listeners involves their continual attempt to answer two questions: Where does this material fit in the overall "logic" of the message, and what does this material have to do with me? Introductions don't have to spell out the answers to those questions, but if they ignore them completely, they do so at great peril.

Introductions are also "here" when they guide the hearer through the first step of the sermon journey in the way in which these listeners can take that step. This involves strategy ... and pastoral sensitivity. To begin a sermon with a detailed background exegesis of a biblical text may make perfectly good sense with one congregation, and yet be communicational suicide with another.

5. Introductions anticipate the "there" of the sermon when they help to shape in the hearer's mind a more or less accurate impression of where the sermon will go. Nichols is also helpful in describing how this works:

When a message begins, a kind of mental search mission starts in the mind of the hearers. From their vast internal computer of stored experience comes a set of meanings, images, and previous understandings to which the unfamiliar incoming message is referred for translation, so to speak. That is the "story," like the accompaniment roll of a player piano, or a film clip backing up the commentary of the evening television news. As soon as that happens, which as a rule takes something like a billionth of a second, communication has become essentially a receiver phenomenon. The meaning of the message is not "transmitted," as we sometimes mistakenly say; it is, so to speak, "transgenerated" in the awareness of the hearer, reassembled in the context of his or her own story. ${ }^{\text {? }}$

Since hearers listen faster than speakers speak, they are "running ahead," anticipating where the message is going, deciding if, in fact, they wish to go there. The introduction provides clues - both of the communicational and meta-communicational variety - about this journey. Indeed, implicit in each introduction is more of a "covenant" than a contract: a promise made in the context of trust that, when this sermon is done, we will have arrived together in a more or less agreed upon place. I keep saying "more or less" because I want to protect the value of unpredictability and surprise in communication. If the hearer is always 
able to guess exactly where the preacher is going, then boredom sets in. If the preacher is always arriving at some spot different from that predicted by the hearer, then the preacher is viewed as idiosyncratic and, thus, communicationally untrustworthy. Nobody wants the weekly experience of checking their luggage in the sermon introduction to Miami, only to arrive in Denver. Occasionally, it's an adventure; weekly, it's a hassle.

In order to see how this process of listener anticipation works, consider the following sermon introduction:

The story of Noah and his ark is not something we grown-ups take very seriously. We tend to regard it as a story for children, and we have our children making replicas of the ark in Sunday school. But it is a very strange thing, really, that we should regard this as a children's story (which is to say a fairy tale), because it is a dark and frightening story. Furthermore, it is a story about ourselves and our world - a story that is quite modern. ${ }^{8}$

Now a hearer listening to this sermon introduction is moving ahead of the preacher, guessing where this sermon will be going, deciding whether to accompany the preacher on this particular journey. In this case, the listeners would have every reason to guess that, when this sermon is concluded, the preacher will have helped them to take the Noah story more seriously by a) exposing its "dark and frightening" side and b) connecting it meaningfully to the real issues of their personal and social lives. In fact, in this introduction the preacher has made a "covenant" with the hearers to do just that. If the preacher fails to do those things, then the communicational covenant is broken. If, sermon after sermon, the preacher breaks covenant with the hearers, the implicit and necessary trust between them is damaged.

Is the above introduction a good one? The answer must be a tentative "yes." It does begin "here" by naming an issue in the hearers' lives (i.e., their current understanding of the Noah story), and it does anticipate "there" (i.e., by promising to expose a new and impor" tant understanding of that story). So far, so good. We cannot yet say, though, that this is an effective introduction, because this assessment must be made in light of the whole sermon. Was the covenant fulfilled? Was the inquisitive, exploratory tone set by the introduction maintained throughout the sermon? In short, an introduction is effective only when it plays a consistent and satisfactory role in the total network of the sermon's communication.

6. One thing implied in the above analysis of the example introduction is that introductions have certain "tonal" qualities (what Nichols would call implicit meta-communication) which are important clues for the hearers about the nature of the overall sermon and, which, in fact, should be consistent with the rest of the sermon. An introduction which raises the theodicy problem in intellectual terms promises a sermon in which preacher and hearer grapple with the issues. To spend the rest of the sermon sloshing around in emotional stories and tearful examples would be, among other infractions, a betrayal of the covenant established in and through the introduction.

It is clear that the understanding of the sermon as an integrated communicational event cannot be confined to a discussion of introductions. It has clear implications for every aspect of the sermon - illustrations, transitions, conclusions, and all the rest. All of the parts of the sermon work together as a system, creating a unified event in the experience of the listeners. Viewed this way, the task of creating the sermon becomes admittedly more complex, more 
demanding pastorally, and more subject to local and congregational criteria than to "universal" literary canons. But this perspective also rescues the sermon from the arena of written discourse, where it has learned much, but to which it finally does not belong, and brings it home again to the world of oral communication.

\section{WORKS CITED}

BARRON, Vance, Sermons for the Celebration of the Christian Year, Nashville: Abingdon Press, 1977.

CRADDOCK, Fred. B., As One Without Authority, Nashville, Abingdon Press, 1978.

DAVIS, H. Grady, Designs for Preaching, Philadelphia: Fortress Press, 1958.

EDWARDS, O.C., Jr., Elements of Homiletic, New York: Pueblo Publishing Company, 1982.

KILLINGER, John, Fundamentals of Preaching, Philadelphia: Fortress Press, 1985.

LOWRY, Eugene L., The Homiletical Plot. The Sermon as Narrative Art, Atlanta: John Knox Press, 1980.

NICHOLS, J. Randall, Building the Word: The Dynamics of Communication and Preaching, San Francisco: Harper and Row, 1980.

\section{FOOTNOTES}

1 Buttrick as quoted in O.C. Edwards, Jr. Elements of Homiletic, p. 74. Buttrick varied his rule from time to time, occasionally adding a fourth element: appropriateness to the particular sermon (see Grady Davis, Design for Preaching, p. 189).

2 John Killinger, Fundamentals of Preaching, p. 83.

3 H. Grady Davis, Design for Preaching, p. 188.

- We do not have to look very far to see the impact of Davis' theory on such modern homileticians as Craddock and Lowry, both of whom have built entire theories (whether they knew it or acknowledged it or not) on a single aspect of Davis' design (for Craddock, inductive logic, and for Lowry, narrative continuity). See Fred B. Craddock, As one Without Authority and Eugene Lowry, The Homiletical Plot.

5 J, Randall Nichols, Building the Word, p. 101

6 Nichols, pp. 102-3.

T Nichols, pp. 69-70.

- Vance Barron, "To Keep Hope Alive," in Sermons for the Celebration of the Christian Year, p. 14. 